\title{
Geographical analysis of climate vulnerability at a regional scale: The case of the Southern Great Plain in Hungary
}

\author{
Jenô Zsolt FARKAS ${ }^{1}$, Edit HOYK ${ }^{1}$ and JÁnos RAKONCZAI ${ }^{2}$
}

\begin{abstract}
This paper provides an example for regional scale analysis of climate vulnerability incorporating environmental as well as socio-economic indicators. Researches have focused on different aspects of climate vulnerability so far, but usually there is little connection between the physical and social dimensions. Our study provides a more complex analysis, which builds on the application of international indices which have been used on the local and regional levels very rarely. In our research we combined physical and human geographical approaches and research techniques. The physical geographical assessment is based on indicators referring to ground water levels and vegetation production, while the human geographical side of the analysis focuses on economic and social sensitivity, adaptation and exposure indices, combined in the so-called socio-economic climate vulnerability index. In the analysis we tried to figure out the most sensitive areas in the Hungarian Southern Great Plain region. The main findings of the study are „hot spots" which coincide on both analyses, therefore, the most sensitive areas under current climate change conditions could be delimited. This study also demonstrates that the resolution of global climate change vulnerability indices is not suitable for regional scale analysis because of the significant territorial differences. Therefore, local or regional scale assessments are needed for the preparation of strategies for the elaboration of mitigation and adaptation policies.
\end{abstract}

Keywords: vulnerability indices, climate change, climate vulnerability analysis, climate sensitivity, Hungary.

\section{Introduction}

Due to its serious consequences on mankind, there is a need to assess the effects of climate change in a more complex way. The changes of climate have spatial variations and affect the various countries and regions differently (GLANTZ, M.H. 1995; O’BRIEN, K.L. and LeichenKo, R.M. 2000; LobelL, D.B. et al. 2011), therefore, policy-makers on the subnational level need decision support tools which are able to summarize the situation of their regions in a simple and effective way (HANGER, S. et al. 2013). One of these tools can be the usage of global climate vulnerability indices which appeared in the last decade such as the Global Climate Risk Index from
Germanwatch (https://germanwatch.org 2006) or the ND-GAIN index from the University of Notre Dame (http://www.gain.org 2014). While they have a solid scientific background, they are not suitable for supporting policy-making and other related tasks (DE SHerbinin, A. 2014).

To achieve this goal, the scale of the climate vulnerability analysis must be reduced to regional, sub-regional or local level. In recent years the modelling of climate change and its effects had a leap forward in terms of spatial resolution which enables deeper understanding of the effects from the viewpoint of the environment, economy and society (Fowler, H.J. et al. 2007; Christensen, J.H. et al. 2007; Mearns, L.O. et al. 2009; JАСOB,

\footnotetext{
${ }^{1}$ Hungarian Academy of Sciences, CERS Institute for Regional Studies, 6000 Kecskemét, Rákóczi út 3. H-6000 E-mails: farkas.jeno@krtk.mta.hu; hoyk.edit@krtk.mta.hu

${ }^{2}$ University of Szeged, Department of Physical Geography and Geoinformatics, H-6722 Szeged, Egyetem u. 2. E-mail: J.Rakonczai@geo.u-szeged.hu
} 
D. et al. 2014). While at the end of the 1990s economists only tried to identify those sectors that were the most vulnerable to any change (Dercon, S. and Krishnan, P. 1996; Scoones, I. 1998), in the last few years, due to improvements in modelling, the number of publications providing numerical analysis of economic and social impacts on regional level has been continuously increasing (Sсотт, D. et al. 2008; AAHeim, A. et al. 2012; PANDEY, R. and Jha, S.K. 2012; WARner, K. and Geest, K. 2013). At the same time the interest of social sciences has also turned towards this issue (PAtz, J.A. et al. 2005; Hunt, A. and Watkiss, P. 2011; IPCC 2014). The experiences of the heatwave in Western Europe in 2003, the water scarcity in Barcelona in 2008, or the floods in South-Eastern Europe in early autumn of 2014 showed that the most vulnerable and deprived social groups have also lower adaptability to extreme weather conditions and to the challenges caused by climate change (Vincent, K. 2004).

In this paper we want to make a brief assessment of the global climate vulnerability indices and to carry out a regional-scale climate vulnerability analysis in the Southern Great Plain Region in Hungary. In the course of research the following questions were addressed:

- What does the climate vulnerability mean at different geographical scales, and how this term can be interpreted in geography?

- What are the main vulnerability factors regarding climate change in Hungary and especially in the Southern Great Plain Region?

- What types of spatial differences are to be expected regarding to the natural, economic and social systems of the Southern Great Plain at the settlement level?

- What can be the role and function of the dual nature of geography in the research of such a complex phenomenon?

The last question about the role of geography is important both in preparation of policy documents and elaboration of adaptation strategies because of the dual nature of geography, the complex methods and con- cepts geographers use when investigating the effects of climate change. It is an intriguing question whether geographers succeed in "developing" appropriate synergies between the two sides of geography when responding such questions like climate change. This dilemma arose not only in Hungarian but also in the Anglo-Saxon geography, as professional debates and scientific publications reflect (Pollard, J.S. et al. 2008; Castree, N. 2014).

\section{Assessment of global climate vulnerability indices and the concept behind them}

There are a lot of climate vulnerability indices applied by various institutions nowadays. KREFT, S. and his colleagues (2016) created the Climate Risk Index (CRI), on the base of hazardous weather events. Precipitation, floods and landslides were the major causes of damage in 2014. High incidence of extreme precipitation matches with scientific expectations of accelerated hydrological cycles caused by climate warming. Serbia, the Islamic Republic of Afghanistan as well as Bosnia and Herzegovina were identified as the most affected countries followed by the Philippines, Pakistan and Bulgaria. Two of the three most affected countries in 2014 where hit by the heaviest rainfalls and worst floods since records began 120 years ago (KREFT, S. et al. 2016). The index is calculated on the basis of deaths caused by natural disasters, remediation costs, loss of GDP and Human Development Index (HDI). According to this calculation Hungary occupies the $60^{\text {th }}$ position among sixty-two European countries, where aridification, droughts, or groundwater level sinking can be clearly linked with effects of climate change.

The Nature Serve organisation in the US elaborated the Climate Change Vulnerability Index (CCVI), which identifies plant and animal species that are particularly vulnerable to the effects of climate change (www.natureserve.org). It can be used for the evaluation of the natural components of climate vulnerability, but the index was experimented only 
for the US, so it cannot be used for international comparisons.

Another CCVI was elaborated by UN Office for the Coordination of Humanitarian Affairs focusing on global crises and disasters (www.reliefweb.int). In the case of Hungary, the red mud sludge disaster in 2010 and the flood in 2013 were recorded. In our opinion, this approach has a limited scope, and we need more indicators for climate vulnerability evaluations.

Verisk Maplecroft, which is a leading global risk research and forecasting company, made another CCVI. It evaluates 42 social, economic and environmental factors to assess national vulnerabilities across three core areas. These indicators include: exposure to climate-related natural disasters and sea-level rise; human sensitivity in terms of population patterns, development, natural resources, agricultural dependency and conflicts; thirdly, the index assesses future vulnerability by considering the adaptive capacity of a country's government and infrastructure to combat climate change (www.maplecroft.com). In this evaluation Bangladesh, India and Madagascar are the most vulnerable countries in the world. The resolution of the CCVI map is $22 \mathrm{~km}^{2}$ and it shows distinct spatial differences only for the bigger countries for example Russia or Canada.

Wheeler, D. (2011), as member of the Centre for Global Development, created the Climate Vulnerability (CV) index, which displays country rankings for four dimensions of climate impact: Extreme Weather, Sea Level Rise, Agricultural Productivity Loss and Overall. Based on his CV index China, India and Bangladesh are the most vulnerable countries regarding the effects of climate change. Hungary's climate vulnerability is low $(\mathrm{CV}=0.025)$, but for example Kazakhstan's index is lower (CV $=-0.237)$, which shows the strong differences between sub-indices used for CVI calculations.

Indian Climate Vulnerability Index consists of household parameters of all the three dimensions of vulnerability such as Exposure, Sensitivity and Adaptive Capability. Exposure is defined by 'Natural disaster and Climate variability', whereas Sensitivity by 'Health', 'Food', and 'Water' and Adaptive Capability by 'Socio-demographic profile', 'Livelihood strategies', and 'Social networks'. The CVI vulnerable status ranges from high (0) to low (1) (PAndey, R. and JhA, S.K. 2012). This research is very similar to our approach, based on sub-indices focusing on natural and social problems.

The University of Notre Dame created the so-called ND-GAIN Country Index (Notre Dame Global Adaptation Initiative). It summarizes a country's vulnerability to climate change and other global challenges in combination with its readiness to improve resilience (www.http://index.gain. org/). This index continuously monitors and analyses 45 indicators for 192 countries in order to assess climate change related vulnerabilities and readiness for improvement. The top five countries are Denmark, New Zealand, Norway, Singapore and the United Kingdom, while the last five countries are Sudan, Burundi, Eritrea, Chad and Central African Republic. Hungary is in the middle of the list, with deteriorating tendency. This ranking is based on a wide group of indicators; therefore, we think that ND-GAIN Country Index is more useful than other indices based on very few indicators.

All the aforementioned international investigations on climate vulnerability are based on the concept of vulnerability. According to Pittman, J. et al. (2011) vulnerability can be defined according to three main components: exposure, sensitivity and adaptive capacity. In this respect exposure means the lack of protection against possible risks in the examined area/sector, and it can be identified with the effects (e.g. water quantities, climatic factors, economic-social framework). Sensitivity means the totality of the social, economic, political, institutional, cultural reactions against the effects. Finally, adaptive capacity is an answer to exposure; how a given country, economic sector, social group is able to prevent the harmful effects. The adaptive capacity is determined by the economic situation, the level of economic development, the information, the infrastructure, the knowledge 
level and abilities of the society, the local and regional level institutional set-up, and the wider socio-economic and political processes.

Vulnerability can be examined from different aspects that are summarized by FüsseL, H.M. (2007). The most widespread approach is based on risk analysis which focuses on the elements that are particularly exposed to climate change. The socio-economic approach of risk analysis puts emphasis on humans, highlighting the extent to which a certain social group is vulnerable and why. The combination of natural and social approaches is the integrated approach, which has its roots in geography and human ecology. Vulnerability can be approached also on the basis of resilience, when applying the concept of flexible adaptability borrowed from ecology to analyse the effects of the climate change and to define the extent of vulnerability (Lendvay, M. 2016).

Finally, it is also important to emphasise that the concept of vulnerability can be applied in the same way at settlement, country or continental level. However, the selected indicators and factors for the analysis should have specific regional relevance because this has a significant influence on the results (Holsten, A. and Kropp, J.P. 2012). In this sense global or continental scale climate vulnerability scores/rankings might be misleading at regional scale, however, there is an opportunity to identify the most relevant indicators and sectors related to a particular region which are likely to give better results than a uniformed approach.

\section{Physical and socio-economic factors of climate vulnerability in Hungary}

Climate change in Hungary - regarding the climate indicators - is primarily characterized by increasing drought sensitivity. Calculations based on the Pálfai aridity index and the assumed climate change scenarios say that the national average of aridity index may increase by 12.5 per cent in the next 25-30 years (PÁlfai, I. 2007).
Damages caused by drought are closely linked with changes in the rainfall distribution. Rainfall in Hungary will be increasingly infrequent, and will be accompanied by higher temperature, consequently, the potential evapotranspiration will increase, and this makes the groundwater reserves more important (VIG, P. 2009; Millán, M. 2014). However, the source of water is steadily decreasing which not only increases the vulnerability of the soils but also its flora, and human activities such as agricultural production too. Therefore, fluctuating crop yields due to the weather conditions can be used for the determination of climate vulnerability, however soil characteristics should also be taken into account (SISÁK, I. et al. 2009).

The extreme occurrences of high temperatures are highlighted by the heatwaves in a tangible way. Several studies have shown that significantly longer heatwaves with higher temperatures can be expected in the future, which can last throughout the entire summer. On the basis of the models hottest temperature records of the 20th century may be exceeded even by $12{ }^{\circ} \mathrm{C}$ (Révész, A. and Szenteleki, K. 2007). This demonstrates that Hungary's climate will drastically change in the future, and the number of extreme events will increase, of which the most dangerous will be the heatwaves beside the increasing incidence of storms, the high intensity precipitation and the more frequent flash floods (NovÁKY, B. 2007).

Climatic changes have a direct impact on vegetation and crop production (Olesen, J.E. et al. 2011; Wilcox, J. and MaKowsKi, D. 2014; LADÁNYI, Zs. et al. 2016). Agriculture is one of the most vulnerable sectors regarding climate change, therefore, its adaptive capacity is a serious issue. Responses are not the same in different countries (VANSCHOENWINKEL, J. et al. 2016), thus, evaluation of the adaptation of agriculture play a significant role in vulnerability assessments.

Beyond the aforementioned methods and indicators, geographical analogy can also be used for the determination of environmental vulnerability. This method is about searching such areas where current climate condi- 
tions are similar to what the examined area may have in the future - so it can help to see the potential effects of the climate change (Horváth, L. 2007). This approach is very useful in identifying new plants and techniques for agricultural production.

It is also important to monitor the changes of the natural vegetation. The vulnerability of the climate zonal forest associations is great, particularly at higher altitudes in Hungary (Czúcz, B. et al. 2010). At the same time in the lowland associations wetlands, salt meadows, floodplain associations are in danger due to the disappearance of water.

The effects of climate change on the society and economy occur indirectly through the natural environment. Generally, the effects are the most serious in those sectors from an economic point of view - which are closely linked to the natural environment, e.g. agriculture, forestry and tourism.

Economists seek to assess the expected damages in monetary-term in order to make the impact of climate change more tangible. In connection with the drop of GDP different calculations and assumptions have been carried out. Starting from the double $\mathrm{CO}_{2}$ emission (compared to pre-industrial levels) the biggest drop in GDP is expected in Africa, it is followed by the Middle East, the Pacific region and Latin America (ToL, R.S.J. 1998). FANKHAuser, S. and Tol, R.S.J. (2005) forecast on average a 5 per cent GDP decrease at $3{ }^{\circ} \mathrm{C}$ temperature increase, although with substantial differences accross countries. At the same time other models predict 1-15 per cent decrease of GDP at $3{ }^{\circ} \mathrm{C}$ increase over the next 20-30 years ( $\mathrm{Yu}, \mathrm{W}$. et al. 2013).

Agriculture is high on the list of sectors which are seriously affected by climate change. Hungary is situated on the boundary of plant production zones and relatively minor climatic changes could significantly change the agro-ecological conditions. Damages caused by adverse climatic conditions are significant from a financial point of view as well; e.g. in 2007 - due to the combined effects of extreme events - there was a loss of 500 million USD in agriculture and forestry (GAÁL, M. et al. 2009). In agricultural production the horticulture is one of the most sensitive sectors, including fruit production, which is particularly vulnerable to spring frost damages, early autumn frosts, the winter lasting cold, as well as drought, excessive rain, extremely high temperatures, or hailstorms (GondA, I. 2009).

International publications dealing with tourism also extensively address the effects of climate change, as summarized by BECKEN, S. (2013). It should be noted that this sector may be less exposed in Hungary. Adverse effects linked to the climate change may have negative effects on city tourism in particular in the case of lasting heatwaves.

Moving onto the social effects of climate change, they may be understood best through various social problems and challenges that can be linked with it. The level of poverty, the differences in access to resources, the volume of migration from peripheral regions towards the centre may provide indicators which can help to assess and quantify the social consequences (GASPER, R. et al. 2011).

International research results indicate that big cities are more vulnerable to the effects of climate change than rural areas. The vulnerability of human settlements is strongly influenced by size, or economic functions. Their vulnerability is expressed in lack of energy, damage in the infrastructure, industrial damages, diseases, higher mortality rates caused by the heatwaves, food shortages and water scarcity (GASPER, R. et al. 2011; LANKAO, R.P. and Quin, H. 2011). Therefore, indicators of social vulnerability should include the economic situation of the local community, the growth rate of the population, and its age, sex and ethnic composition (Borden, K.A. et al. 2007).

\section{Research methods}

Geographical framework of the study: The Southern Great Plain

The Southern Great Plain region of Hungary has a population of 1,3 million people, and 
located in the South-Eastern part of Hungary. The total area of the Southern Great Plain is $18,339 \mathrm{~km}^{2}$, which is about one fifth of the total area of Hungary. Population density is below the national average (72 people $\left./ \mathrm{km}^{2}\right)$, however, urban ratio is relatively high, 67.9 per cent of the inhabitants live in cities (the largest city is Szeged with ca. 165 thousand inhabitants). Yet, the high number of scattered farmsteads and outskirts provide the landscape of the region a rather rural character. Administratively the region is divided into three counties: Bács-Kiskun, Csongrád and Békés (Figure 1). The landscape of the region preserves the typical appearance of the famous Hungarian "Puszta" (steppe), featuring four major rivers (Tisza, Körös, Maros and Danube) and three national parks (Duna-Dráva NP, Kiskunság NP and Körös-Maros NP).
Southern Great Plain is typically an agricultural region; 85 per cent of its land is used for agriculture. Crop production, horticulture and animal husbandry play a decisive role in the local economy. In term of soils, large part of the region is covered by humus poor sandy soils, which is widely used for fruit and vegetable production. The southern and eastern part of the region is covered by valuable chernozem soils formed on loess. Agricultural production is the most intensive in this part of the region, the main crops are: wheat, maize, sunflower, sugar beet etc. In addition to agriculture, food industry and light industry form the basis of the economy. The largest foreign direct investment has been made in the region by Daimler Group in 2009 when a Mercedes-Benz factory was established in Kecskemét.

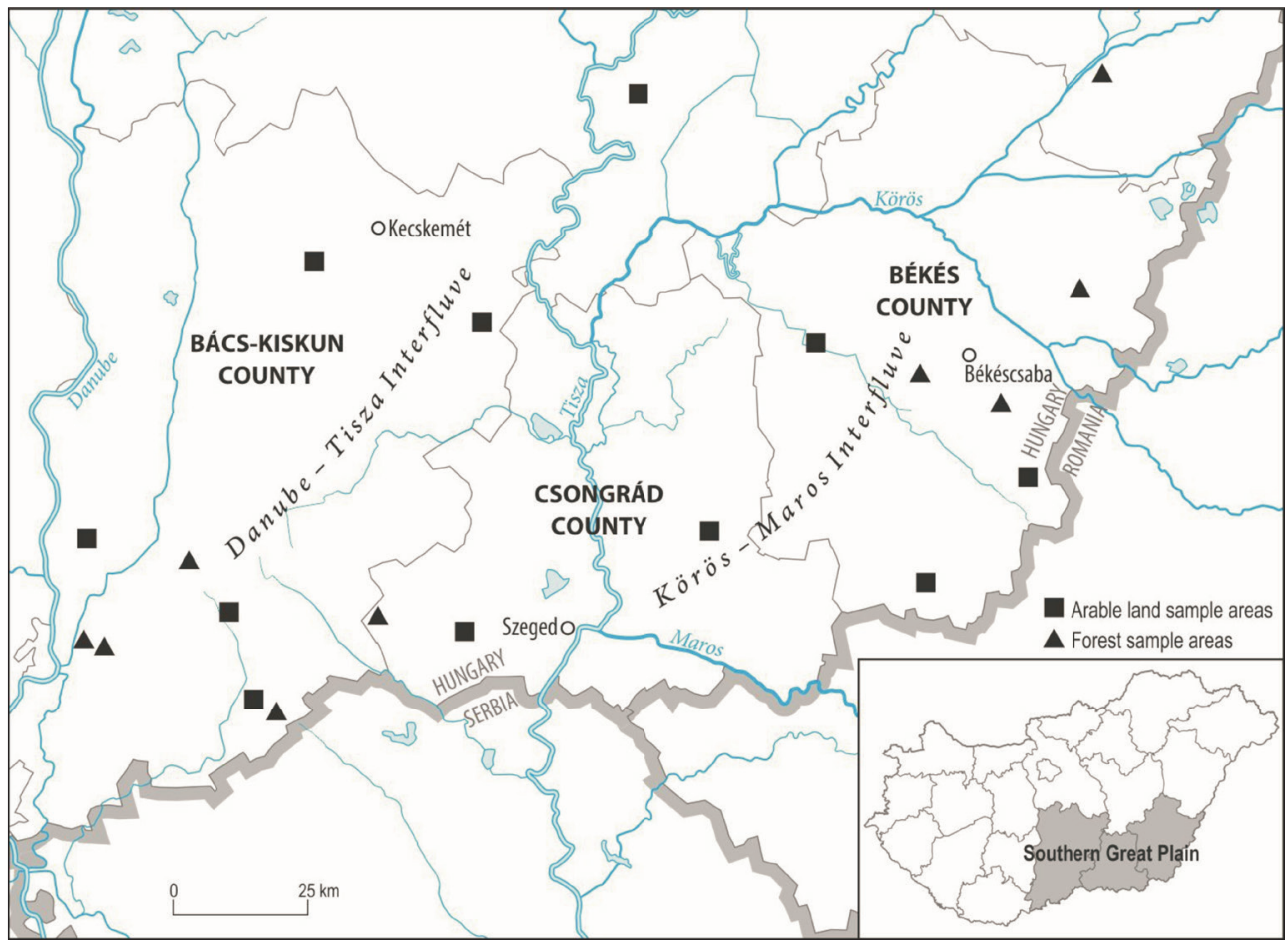

Fig. 1. Map of the study area 
Measuring environmental aspects climate vulnerability

Landscape change is a clear evidence of climate change. Therefore, indicators that connect landscape changes with climatic factors should be considered. Based on our earlier studies it is mainly the change of vegetation that relates to climate change, and the reasons for the change are rainwater and groundwater and - occasionally - soil change. Figure 2. shows the process of landscape change under climate change.

To identify the spatial pattern of climate vulnerability within the region from an environmental point of view we applied the following method:

(1) GIS based analysis of changes in the groundwater level of the Danube-Tisza and the Körös-Maros Interfluves. One of the first observed consequences of the climate change was the decrease of groundwater levels in the Danube-Tisza Interfluve, which generated a serious discussion about the reasons of this phenomenon (PÁlfai, I. 1994). We have constructed a re-controlled and normalized database of groundwater levels for the interfluves.

(2) Analysis of biomass production of forests and arable lands based on remotely sensed satellite data. We used vegetation indices (NDVI, EVI) to approximate the biomass production of 12 sample areas (RAKONCZAI, J. et al. 2012).

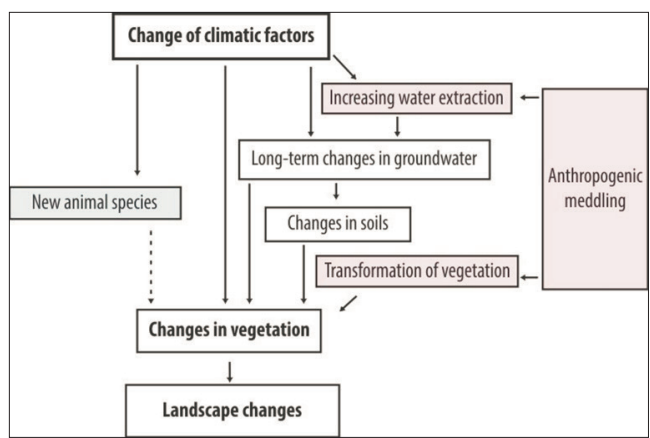

Fig. 2. The process of landscape change due to climate change
Measuring socio-economic aspects of climate vulnerability

In setting up the framework of the socio-economic climate vulnerability index (later refer as CVI) we relied mainly on domestic studies based on the CIVAS $^{3}$ model which was developed in the CLAVIER ${ }^{4}$ project. We relied on the results of the document prepared by Hungarian Non-profit Ltd. for Regional Development and Town Planning entitled „Four-years Program to Prevent the Adverse Effects of Climate Change 2010-2013" (NFGM, VÁTI 2010), and the seminar entitled ,Regional Assessment of the Climate Vulnerability by the Example of NCCS ${ }^{5 \prime \prime}$ held by the National Adaptation Centre (SElmeczi, P. 2014). Regarding the calculation method of the CVI we mainly used the work of HaHN, M.B., Riederer, A.M. and Foster, S.O. (2009), in which a Livelihood Vulnerability Index was established in a Mozambican case study.

On the basis of these sources a settlement level climate vulnerability index was defined using indicators referring to the exposure, the socio-economic sensitivity and the adaptation capacity of the local society. As a first step those social characteristics and economic sectors were defined, which are deemed vulnerable to climate changes, further we chose those indicators which seemed to be suitable to explore spatial differences. The economic sensitivity sub-index components are: the ratio of the agricultural sector in employment (2011), labour income share of the small-scale agricultural sector (2011) and ratio of industry in employment (2011).

The emphasis was placed on the weight of the primary sector as the most vulnerable among the economic sectors. It should be noted that the structure of the sector is dual in the region, since micro-regions of the nonindustrial and industrial farming are chang-

\footnotetext{
${ }^{3}$ Climate Impact and Vulnerability Assessment Scheme.

${ }^{4}$ CLAVIER: Climate Change and Variability - project focused on Central and Eastern Europe.

${ }^{5}$ NCCS: National Climate Change Strategy.
} 
ing. That's why we applied two different indicators for this topic.

The proportion of the employees working in the industry is included in the sub-index in addition to the two agricultural indicators, since for example the construction industry or some part of the processing industry are highly exposed to the climate change due to technological reasons or because the protection of workers during heatwaves requires the suspension of the work. It might bring a significant loss of effectiveness and lastly could entail a loss of income and profit.

Indicators of the social sensitivity sub-index are the following: patients of respiratory and cardiac distress per 1,000 inhabitants (average of 2011-2012), number of visits to a general practitioner per 1,000 inhabitants (average of 2011-2012), proportion of people aged over 65 among permanent residents (2012). In the setup of this sub-index we focused on the social groups which are more sensitive to the climate change due to their age or health conditions. One of the relevant indicators is the proportion of patients with respiratory diseases reflecting the growing presence of allergenic plants and prolonged allergy season. The cardiac patients are highly sensitive to climatic affects, while the number of visits to the general practitioner basically was applied to represent general health status of the local communities. The proportion of people aged 65 or older has been chosen as an indicator since the literature and experiences of the heatwave of 2003 in Paris showed that elderly people are highly affected by the increased length of heatwaves and heat days.

The adaptation sub-index contains the following elements: per capita income (2012), proportion of graduates within the $25+$ population (2011) and the number of scientific, technicaltechnological enterprises per 1,000 inhabitants (2012). Both in the international and national literature, the income of the local community is closely connected to the adaptation capacity of the local society. The other two indicators in the adaptation sub-index represent the intel- lectual, scientific and technical potential which can be used in the adaptation process.

Finally, we have mapped the exposure to climate change of each settlement, and we tried to determine an exposure sub-index. Diverging from the literature - and from the CIVAS model - we did not use the national climate modelling results because we thought that the factual changes can provide appropriate indication for the estimation of exposure. The exposure sub-index contains the following indicators: change of the number of heatwave days between 1980-2010, change of average temperature between 1980-2010, change of rainwater quantity 1980-2010, volume of urban land (2011) and the quantity of communal water supplied in the settlements (2012). To formulate this subindex, in addition to the climate indicators two further indicators were selected, which are able to reflect the effects of changes. One of them is the volume of urban land which wishes to represent the urban heat-island effect. It has a great importance because the consequences of the heatwave days are further enhanced by the buildings and the infrastructural objects. The other selected indicator was the supplied water quantity in the settlements, since it is believed that its scarcity will determine the future of the Southern Great Plain basically.

We calculated the socio-economic climate vulnerability index on settlement level because we assume that there are significant spatial differences in the effects of the climate change even at the micro-geographical scale. Also, actions against the immediate effects of climate change must be taken on local level. The calculation of the sub-indices and the climate vulnerability index was performed according to the method defined by HaHN and his colleagues (2009). In the case of the sub-indices the indicators $(I x)$ have been decoupled from the units by the Min-Max normalization, and have been transformed between ranges $0-1$ ( Inormx $_{\text {X }}$ ).

$$
I_{\text {normx }}=\frac{I_{x}-I_{\min }}{I_{\max }-I_{\min }}
$$


After that arithmetic mean was calculated from the values of the indicators $\left(I_{\text {normx }}\right.$ ) without weighting, which gave the results of the sub-indices $\left(S I_{x}\right)$.

$$
S I_{x}=\frac{I_{\text {norm } 1}+I_{\text {norm } 2}+\ldots I_{\text {normx }}}{x}
$$

The summarized climate vulnerability index (CVI) value was defined in such way that the arithmetic mean of the indicators included in the social and economic sensitivity sub-index was deducted from the index of exposure, and the given value was multiplied by the value of the adaptation index.

$$
C V I=\left(S I_{\text {exp }}-\left(S I_{S O C}+S I_{\text {eco }}\right)\right) \cdot S I_{\text {adapt }}
$$

\section{Results and Discussion - climate vulnerability of the Southern Great Plain}

\section{Climate vulnerability based on change of ground} water level

Aggregated data showing changes of ground water resources from 1961 to 2010 were used for two sub-regions: the Danube-Tisza Interfluve and the Körös-Maros Interfluve (Figure 3).

As data demonstrate the ground water level in the Körös-Maros Interfluve is more stable, and the quantity of the annual rainfall causes less variability, while in the case of DanubeTisza Interfluve some drier or wetter years can result even $2 \mathrm{~km}^{3}$ change of the water resources. In the last three decades the overall water scarcity exceeded $7-8 \mathrm{~km}^{3}$ by our calculation in the Southern Great Plain. MAjor, P. (1994) studied the long-term reasons of the decrease and identified that there was a drier period between 1971 and 1985 when the amount of precipitation was less by $1,000 \mathrm{~mm}$ in the area compared to the long-term average. The changes in precipitation of the last decades show extreme variability rather than decreasing in quantity. There is a slight increase in annual precipitation in the Southern Great Plain in the last 55 years. At the same time the annual mean temperature shows a $1.5^{\circ} \mathrm{C}$ increase which means that the evaporation loss

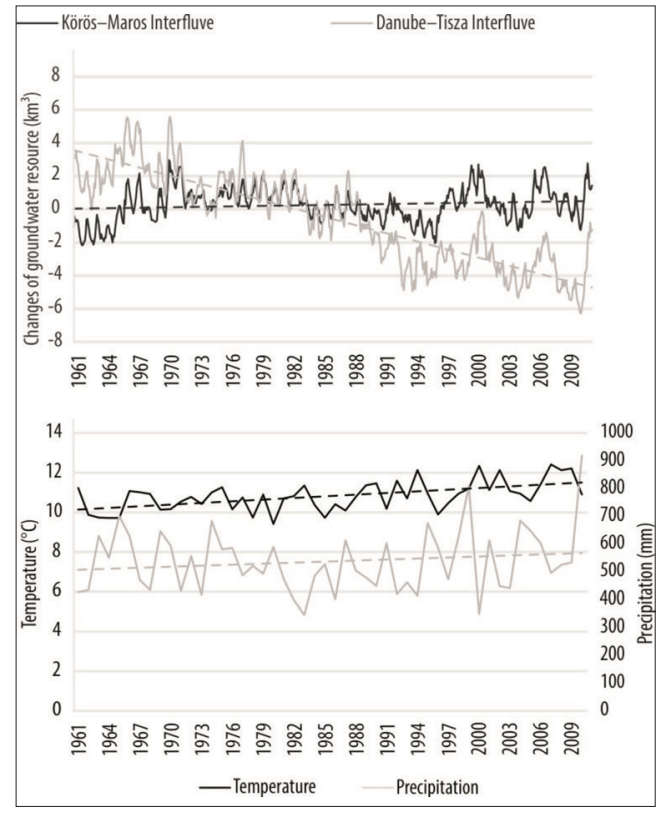

Fig. 3. Monthly aggregated changes of ground water resources together with annual mean temperature and precipitation (1961-2010)

has significantly risen. This means the rainfall could not be utilized by the vegetation and the soils, so it causes water scarcity even in years with higher precipitation.

Another issue related to the ground water level can be understood in hydrological aspect; since the interfluves are above their surroundings (the Danube-Tisza Interfluve by 30-50 $\mathrm{m}$ and the Körös-Maros Interfluve by $10-15 \mathrm{~m}$ ) the ground water cannot be rebuilt from the surface waters (from the rivers) this is only possible from rainwater sources.

\section{Climate vulnerability based on the analysis of} biomass production

In the course of our investigations of biomass we analysed the vegetation dynamics of the main forest types (black pine and black locust) mainly in the areas affected by the most significant decrease of ground water level (all sample areas can be seen on Figure 1) on the 
basis of 13 years data. Forests have been also chosen as control areas where the decrease of the ground water level is less significant, thus, the ground water is more easily accessible for the trees. Our results show that the areas with deeply decreased ground water level (where the more demanding tree vegetation dried out in several places) and the annual biomass quantity of the forests correlate strongly with the spring and summer precipitation. In contrast, the control forests are rather depend on the winter period or the combination of the winter and vegetation periods. Which means they depend on the ground water significantly, because the precipitation of the winter period is the main supply for the ground water. It was recorded that in the areas with a significant decrease of ground water level in the Danube-Tisza Interfluve, trees are less dependent on the ground water (since its water demand is ensured from other source) and more exposed to the capricious rainfall pattern (Figure 4).

In the next phase of our research we analysed the vegetation index data of agricul-

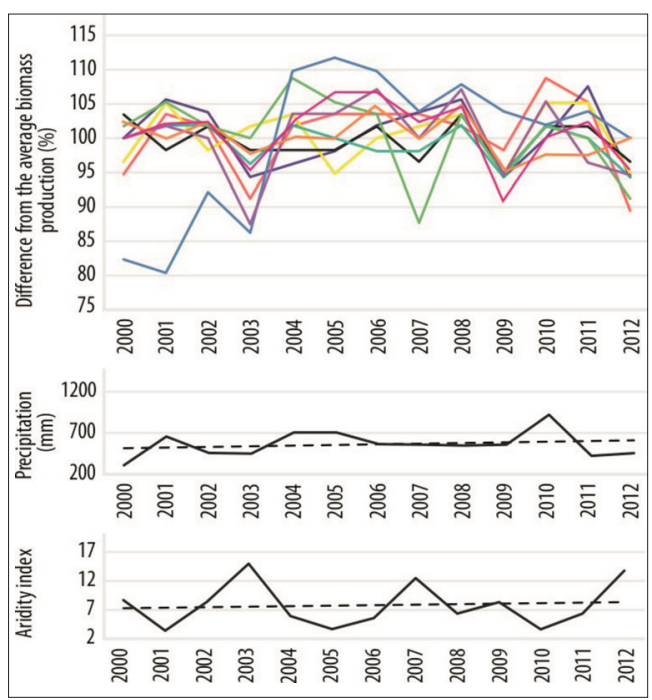

Fig. 4. Changes in biomass production of forest sample areas related to annual PÁLfAI aridity index and precipitation tural areas too. We selected mostly arable land in 12 sample areas, however, local soils represent different types and have varied morphological status and fertility.

Determining the biomass production of our sample areas and comparing them to the Pálfai aridity index, we found especially strong correlation with dry years. In the case of the highest biomass production we did not gain such a clear picture. It could be expected that the rainiest year of 2010 is the most productive, but it is true only in some cases. In almost half of the areas the year of 2004 showed the highest productivity. This duality has straightforward reasons. On the one hand, too much precipitation could be harmful, as there is inland water coverage at that time, on the other hand, the temporal distribution of the precipitation is very important for the crops, and in 2004 the growing period months had rains evenly, ensuring the optimal growth of plants.

In our research it was a little bit surprising that the biomass production of the arable lands (please note that this is not the quantity of the harvested crops) almost uniformly depends on the rainfall even where irrigation is available. These results suggest that in a drying climate, irrigation does not necessarily solve the problem of crop yield stability, since the atmospheric drought has a great influence on the growth of plants.

\section{Climate vulnerability of the local economy and society}

According to our socio-economic climate vulnerability index above-average sensitive settlements in the Southern Great Plain were delimited in larger groups only in BácsKiskun County, lying in the South-western direction from Kecskemét to the Serbian border. Contrary to this in Csongrád and Békés counties only 2-3 settlements formed "hot spots". They are located basically on the border between Bács-Kiskun and Csongrád counties, and in the neighbouring regions of Csongrád and Békés, which can be labelled 
as inner peripheries. In addition to this, vulnerable areas at the micro-region scale can be found along the southern border of Hungary (outer peripheries) (Figure 5). These results confirm that climate vulnerability is spatially highly differentiated, and it is worth investigating also the settlement size resolution.

In addition to the regional pattern we have examined climate vulnerability according to settlement size categories. We used the following categories: $1^{\text {st }}$ category: below 2,000 inhabitants (small villages), $2^{\text {nd }}$ category: 2,000-10,000 inhabitants (villages and small towns), $3^{\text {rd }}$ category: $10,000-50,000$ inhabitants (towns); and $4^{\text {th }}$ category: above 50,000 inhabitants (county seats). Figure 6. shows that there are significant differences between these settlement categories especially related to the adaptation capacity.

Examining the differences, we can see that the settlements of the $1^{\text {st }}$ and $2^{\text {nd }}$ categories are only slightly different from each other.
The only exception is the adaptation capacity which means that the population size of a settlement greatly influences the ability of resilience in the economic sensitivity and in the before mentioned adaptation capacity. These two categories can be characterised by the relative importance of agricultural sector and its dominance in local economy and employment. This goes together with lower incomes, less educated and aging population, especially in the settlements of the $1^{\text {st }}$ category.

The climate vulnerability of the $3^{\text {rd }}$ category is slightly better than the previous ones, according to our results. This is because their socio-economic conditions are more advantageous and consequently their adaptation capacity is also significantly higher and their exposure is only slightly bigger. According to our results the towns and the county seats ( $3^{\text {rd }}$ and $4^{\text {th }}$ categories) are the least sensitive to climate change as their economies have been shifted most intensely to the service

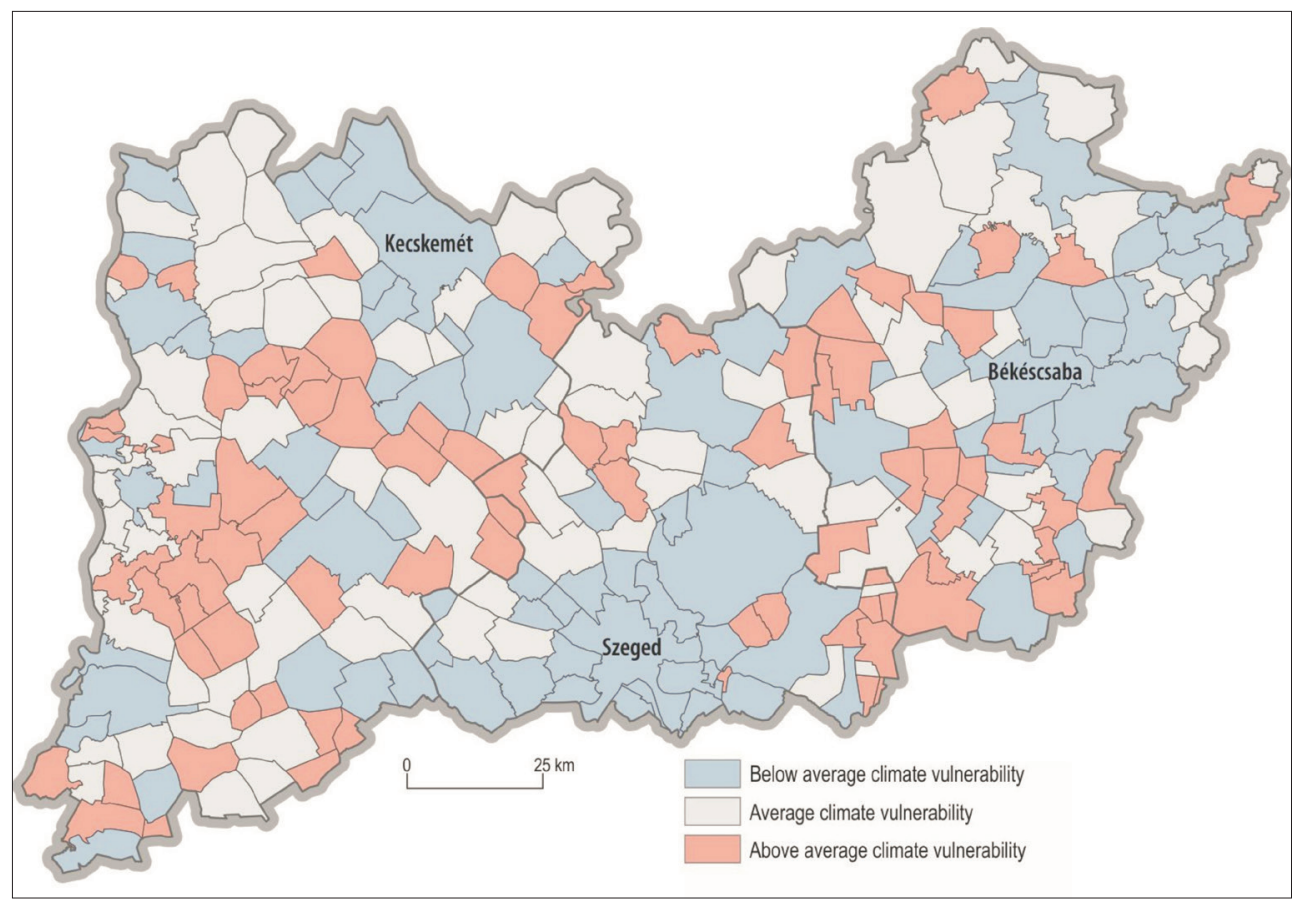

Fig. 5. Socio-economic climate vulnerability 


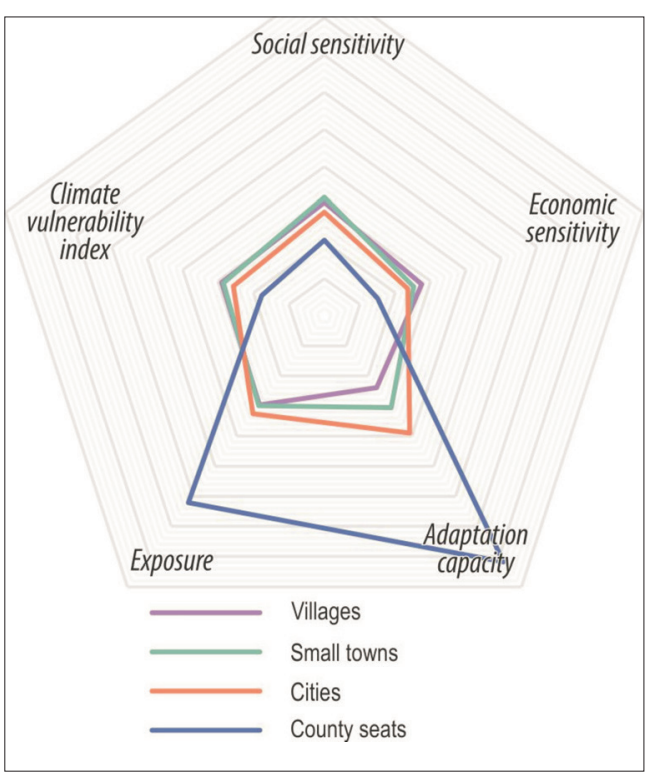

Fig. 6. Socio-economic vulnerability by settlement types

sector, thus, the potential effects of climate change is less pronounced in this case. In both groups the average age of population is younger, their health status is better, the proportions of scientific, technical enterprises and the graduates are higher and the per capita income is also higher which as a whole compensate the significantly larger exposure according to our assessments.

Our findings clearly demonstrate that the larger the number of the population of a settlement is, its exposure to the effects of climate change is also larger (in line with the international literature), however, its adaptation capacity is also stronger, thus, bigger towns are less vulnerable than the smaller settlements. It should be highlighted that certain shortages e.g. shortage of water - cannot be substituted by other resources. So the instability in precipitation and the significant decrease of water flow in the Danube and Tisza rivers could raise serious issues for larger settlements.

To sum up it can be stated that our socioeconomic climate vulnerability index is not suitable for particular numerical comparison of the vulnerability of settlements, but it allows to designate those settlements in the Southern Great Plain which have to pay more attention to the possible effects of climate change due to their economic and social characteristics.

\section{Comparison of the CVI with the results of the} physical geographical findings

In our research, we could not directly aggregate all aspects of sensitivity into one single vulnerability index. While it would have been technically possible by GIS, but legal problems concerning the ownership of the various datasets prevented such an analysis. To solve this problem, we compared only the final maps of the two analyses (Figure 7). Circles show the areas where climate vulnerability is connected with negative climatic and/or anthropogenic effects, which means mainly water extraction for agricultural, or industrial and communal needs. Results of our analysis further support that water scarcity is the main factor of climate vulnerability in the Southern Great Plain. The overlaps in the environmental and socio-economic analysis are strengthening our assumption that climate vulnerability must be investigated in a complex way and with high spatial resolution because of its variability within a small area. The examined regions should be paid more attention by the researchers and regional planners, because these can be the primary sample areas of future researches due to their vulnerability, thus, climate adaptation strategies must be prioritised in their cases.

\section{Conclusions}

In this paper, a comprehensive analysis of the climate vulnerability of the Southern Great Plain Region in Hungary was provided. To begin with we reviewed the various global climate vulnerability indices and the concepts behind them. In general, it can be 


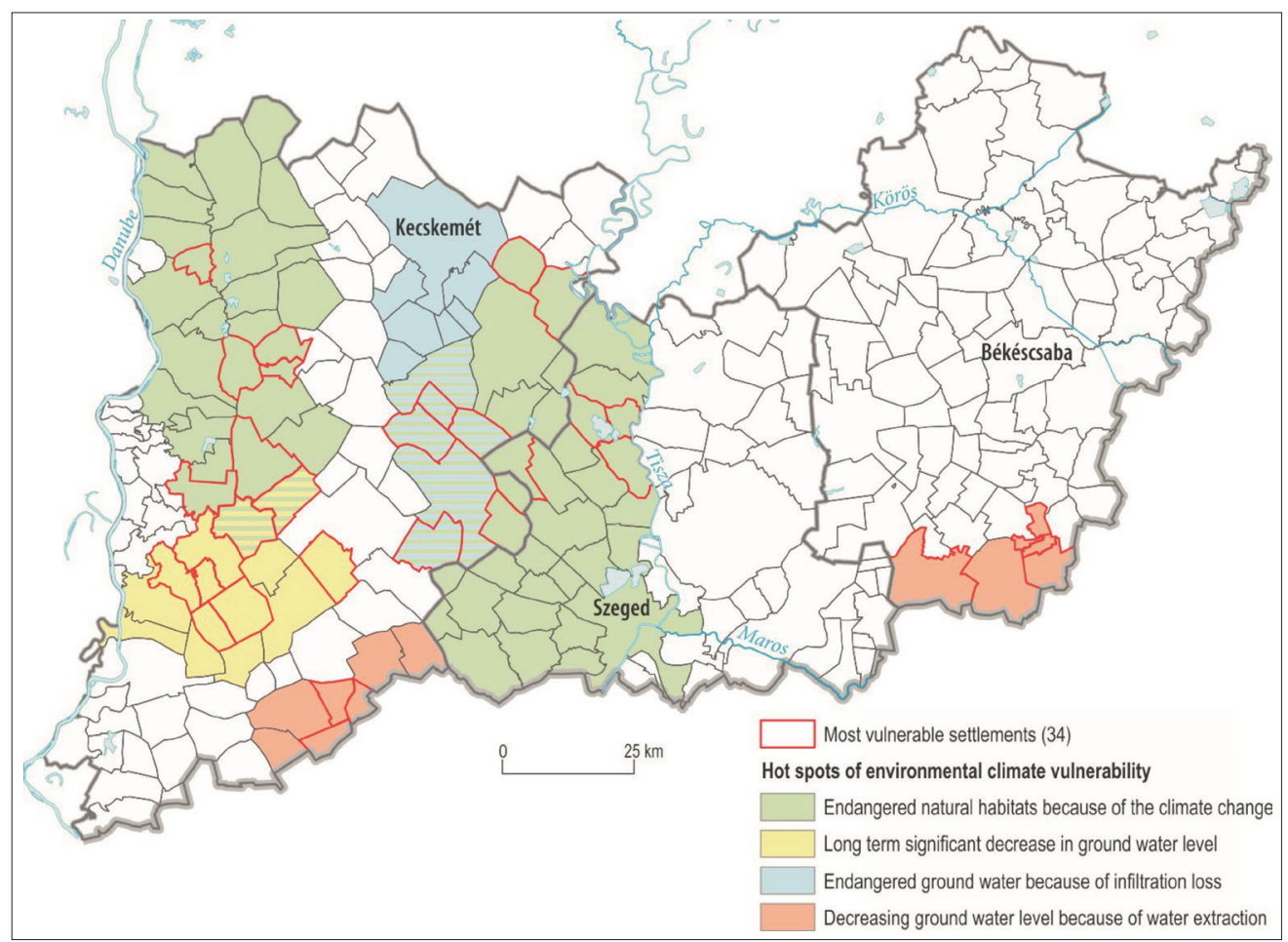

Fig. 7. Geographical overlap among the climatically most vulnerable settlements and the environmental "hot spots" of the Southern Great Plain

concluded that they focus mainly on larger geographical areas (continents and countries) and usually their output is a rank score/list which shows the vulnerability of various countries. The problem of these rankings is that they use very different indicators and the position of a given country can shift significantly. Another important feature of them is that they put the emphasis on the factors that affect well-being. Thus, they tend to forget about the ecosystem which provide ecosystem-services to humans, meanwhile these direct and indirect goods and services are essential for our everyday living as our case study showed. Also their spatial resolutions are low and show significant differences between the vulnerability of neighbouring countries. This fact indicates that analyses with higher spatial resolution are needed.
Our findings show that the concept of vulnerability is applicable on regional level. This is important because it can be used as a framework in the planning of adaptation and the related measures which must be carried out on the local level. Nowadays, climate strategies on the county level are required in Hungary, and this activity is in progress. Our analysis can be a methodological step forward for the elaboration of climate strategies. Holsten, A. and KRорт, J.P. (2012) made a similar analysis in the North Rhine-Westphalia Region. They identified spatial "hot spots" too, which will have to deal with the highest burdens and, therefore, have the highest need for adaptation. Yet, little known about the relationship between climate impacts and adaptive capacity, therefore, we need more and more vulnerability investigations on regional/local scale. 


\section{REFERENCES}

Aaheim, A., Amundsen, H., Dokken, T. and Wei, T. 2012. Impacts and adaptation to climate change in European economies. Global Environmental Change 22. 959-968.

Becken, S. 2013. A review of tourism and climate change as an evolving knowledge domain. Tourism Management Perspectives 6. 53-62.

Borden, K.A., Schmidtlein, M.C., Emrich, Ch. T., Piegorsch, W.W. and Cutter, S.L. 2007. Vulnerability of US Cities to Environmental Hazards. Journal of Homeland Security and Emergency Management 2. 14-27.

Castree, N. 2014. The Anthropocene and geography I: The back story. Geography Compass 8. (7): 436-449.

Christensen, J. H., Carter, T. R., Rummukainen, M. and Amanatidis, G. 2007. Evaluating the performance and utility of regional climate models: the PRUDENCE project. Climatic Change 81. 1-6.

Czúcz, B., Molnár, Zs. and Kröel-Dulay, Gy. 2010. A természetes élővilág és az éghajlatváltozás - a modellezés lehetőségei (The natural wildlife and the climate change - possibilities of modelling). In Meteorológiai Tudományos Napok: Változó éghajlat és következményei a Kárpát-medencében. Ed.: LaKatos, M., Budapest, Országos Meteorológiai Szolgálat, 138-146.

De Sherbinin, A. 2014. Climate change hotspots mapping: what have we learned? Climatic Change 123. (1): 23-37.

Dercon, S. and Krishnan, P. 1996. Income portfolios in rural Ethiopia and Tanzania: choices and constraints. Journal of Development Studies 32. (6): 850-875.

FAnKhauser, S. and Tol, R.S.J. 2005. On climate change and economic growth. Resource and Energy Economics 1. 1-17.

Fowler, H.J., Blenkinsop, S. and Tebaldi, C. 2007. Linking climate change modelling to impacts studies: recent advances in downscaling techniques for hydrological modelling. International Journal of Climatology 27. (12): 1547-1578.

FüssEL, H.M. 2007. Vulnerability: A generally applicable conceptual framework for climate change research. Global Environmental Change 2. 155-167.

GaÁl M., Ladányi M., Szenteleki K. and Hegedús A. 2009. A kertészeti ágazatok klimatikus kockázatainak vizsgálati-módszertani áttekintése (Overview of research methods to evaluate the climatic hazards in horticulture). "Klíma-21” Füzetek. KlímaváltozásHatások-Válaszok 58. 72-81.

Gasper, R., Blohm, A. and Rut, M. 2011. Social and economic impacts of climate change on urban environment. Current Opinion in Environment Sustainability 3. 150-157.
Glantz, M.H. 1995. Assessing the impacts of climate: the issue of winners and losers in a global climate change context. Studies in Environmental Science 65. 41-54.

GondA, I. 2009. Időjárási szélsőségek okozta károk mérséklésének technikai és technológiai lehetőségei a gyümölcsösökben (Possibilities of decreasing damage caused by extreme weather conditions in fruit orchards).,"Klíma-21" Füzetek. KlímaváltozásHatások-Válaszok 58. 45-51.

Hahn, M.B., Riederer, A.M. and Foster, S.O. 2009. The Livelihood Vulnerabilioty Index: A pragmatic approach to assessing risks from climate variability and change - A case study in Mosambique. Global Environmental Change 1. 74-88.

Hanger, S., Pfenninger, S., Dreyfus, M. and Patt, A. 2013. Knowledge and information needs of adaptation policy-makers: an European study. Regional Environmental Change 13. (1): 91-101.

Holsten, A. and Kropp, J.P. 2012. An integrated and transferable climate change vulnerability assessment for regional application. Natural Hazards 64 . (3): 1977-1999.

Horváth, L. 2007. Földrajzi analógia meghatározásának néhány módszere és alkalmazási lehetőségei (Methods to determine geographical analogy and possible applications). "Klíma-21" Füzetek. Klímaváltozás-Hatások-Válaszok 50. 54-61.

Hunt, A. and Watkiss, P. 2011. Climate change impacts and adaptation in cities: a review of the literature. Climatic Change 104. (1): 13-49.

IPCC 2014. Intergovernmental Panel on Climate Change. Climate Change 2014 - Impacts, Adaptation and Vulnerability: Regional Aspects. Cambridge, Cambridge University Press.

Jacob, D., Petersen, J., Eggert, B., Alias, A., Christensen, O.B., Bouwer, L.M. and Georgopoulou, E. 2014. EURO-CORDEX: new high-resolution climate change projections for European impact research. Regional Environmental Change 14. (2): 563-578.

Kreft, S., Eckstein, D., Dorsch, L. and Fischer, L. 2016. Global Climate Risk Index 2016: Who Suffers Most from Extreme Weather Events? Weather-related Loss Events in 2014 and 1995 to 2014. Germanwatch. LadÁNyi, Zs., Blanka, V., József DeÁK, Á., Rakonczai, J. and Mezôsı, G. 2016. Assessment of soil and vegetation changes due to hydrologically driven desalinization process in an alkaline wetland, Hungary. Ecological Complexity 25. 1-10.

LANKAO, R.P. and Quin, H. 2011. Conceptualizing urban vulnerability to global climate and environmental change. Current Opinion in Environmental Sustainability 3. 142-149.

Lendvay, M. 2016. Resilience in post-socialist context: The case of a watermelon producing community 
in Hungary. Hungarian Geographical Bulletin 65. (3): 255-269.

Lobell, D.B., Schlenker, W. and Costa-Roberts, J. 2011. Climate trends and global crop production since 1980. Science 333. (6042): 616-620.

Major, P. 1994. Talajvízszint-süllyedések a DunaTisza közén (Groundwater depletion in the Danube-Tisza Interfluve). In A Duna-Tisza közi hátság vízgazdálkodási problémái. Ed.: PÁlfaI, I., Békéscsaba, Nagyalföld Alapítvány, 17-24.

Mearns, L.O., Gutowski, W., Jones, R., Leung, R., McGinnis, S., Nunes, A. and Qian, Y. 2009. A regional climate change assessment program for North America. Eos 90. (36): 311-311.

Millán, M. 2014. Extreme hydrometeorological events and climate change predictions in Europe. Journal of Hydrology 518. Part B, 206-224.

NFGM, VÁTI 2010. A területfejlesztés 4 éves szakmai programja klímaváltozás hatásainak mérséklésére, 2010 2013. (Four-years program to prevent the adverse effects of climate change 2010-2013). http://www. vati.hu/files/sharedUploads/docs/ttei/A_teruletfejlesztes_klimaprogramja_2010-2013_1.pdf

Nováky, B. 2007. Az ENSZ Éghajlat-változási Kormányközi Testületének jelentése az éghajlatváltozás várható következményeiről. (Report of the UN's Intergovernmental Panel of Climate Change ont he expected consequences of climate change). „Klíma-21" Füzetek. Klímaváltozás-Hatások-Válaszok 50. 6-11.

O'Brien, K L. and Leichenko, R.M. 2000. Double exposure: assessing the impacts of climate change within the context of economic globalization. Global Environmental Change 10. (3): 221-232.

Olesen, J.E., Trnka, M., Kersebaum, K.C., Skjelvåg, A.O., Seguie, B., Peltonen-Sainio, P., Rossi, F., Kozyra, J. and Micale, F. 2011. Impacts and adaptation of European crop production systems to climate change. European Journal of Agronomy 34. (2): 96-112.

Pálfai, I. (ed.) 1994. A Duna-Tisza közi hátság vízgazdálkodási problémái (Water management problems of the Danube-Tisza Interfluve). Békéscsaba, Nagyalföld Alapítvány.

PÁlfAI, I. 2007. Éghajlatváltozás és aszály (Climate change and drought). "Klíma-21" Füzetek. Klímaváltozás-Hatások-Válaszok 49. 59-65.

Pandey, R. and Jha, S.K. 2012. Climate vulnerability index - measure of climate change vulnerability to communities: a case of rural Lower Himalaya, India. Mitigation and Adaptation Strategies for Global Change 17. 487-506.

Patz, J.A., Campbell-Lendrum, D., Holloway, T. and Foley, J. A. 2005. Impact of regional climate change on human health. Nature 438. (7066): 310-317.

Pittman, J., Wittrock, V., Kulshreshtha, S. and Wheaton, E. 2011. Vulnerability to climate change in rural Saskatchewan: Case study of the Rural Municipality of Rudy No. 284. Journal of Rural Studies 1. 83-94.

Pollard, J.S., Oldfield, J., Randalls, S. and Thornes, J.E. 2008. Firm finances, weather derivatives and geography. Geoforum 2. 616-624.

RakonCZai, J., LADÁNYI, Zs., DeÁk, J.Á. and Fehér, Zs. 2012. Indicators of climate change in the landscape: investigation of the soil-groundwater-vegetation connection system in the Great Hungarian Plain. In Review of climate change research program at the University of Szeged (2010-2012). Eds.:RAKONCZAI, J. and LADÁNYI, Zs., Szeged, Institute of Geography and Geology, University of Szeged, 41-58

Révész, A. and Szenteleki, K. 2007. A hőhullámok és a hőmérséklet sztochasztikus viselkedésének vizsgálata (Investigation of the stochastis behaviour of heat waves and temperature) „Klíma-21" Füzetek. Klímaváltozás-Hatások-Válaszok 51. 18-33.

Scoones, I. 1998. Sustainable Rural Livelihoods: A Framework for Analysis. IDS Working Paper 72. Brighton, Institute of Development Studies.

Scott, D., Amelung, B., Becken, S., Ceron, J. P., Dubois, G., Gössling, S. and Simpson, M. 2008. Climate change and tourism: Responding to global challenges. Madrid, World Tourism Organization.

SELmeczi, P. 2014. Az éghajlati sérülékenység a területi értékelése a NÉS példáján (Regional assessment of the climate vulnerability by the example of National Climate Strategy). Climate-Adapt Fórum a tudomány képviselői és az ágazati döntéshozók számára a klímaalkalmazkodás kérdéseiben, VM, 26-27. 06. 2014.

SisÁk, I., Máté, F., Makó, A., SzÁsz, G. and Hausner, Cs. 2009. A talajok klímaérzékenysége (Soil climate sensitivity). "Klíma-21” Füzetek. KlímaváltozásHatások-Válaszok 57.: 31-42.

ToL, R.S.J. 1998. Estimating socio-economic impacts of climate change. Studies in Environmental Science 72. 199-221.

Vanschoenwinkel, J., Mendelsohn, R. and Van Passel, S. 2016. Do Western and Eastern Europe have the same agricultural climate response? Taking adaptive capacity into account. Global Environmental Change 41. 74-87.

VIG, P. 2009. Az inszoláció változásainak hatása az erdők vízháztartására (Effect of changing insolation on the water balance of Hungarian forests). „Klíma-21" Füzetek. Klímaváltozás-Hatások-Válaszok 57. 83-90.

Vincent, K. 2004. Creating an index of social vulnerability to climate change for Africa. East Anglia, Tyndall Centre for Climate Change Research.

Warner, K. and van der Gees, K. 2013. Loss and damage from climate change: local-level evidence from nine vulnerable countries. International Journal of Global Warming 5. (4): 367-386. 
Wheeler, D. 2011. Quantifying Vulnerability to Climate Change: Implications for Adaptation Assistance. Centre for Global Development, Working paper 240.

Wilcox, J. and Makowski, D. 2014. A meta-analysis of the predicted effects of climate change on wheat yields using simulation studies. Field Crops Research 156. 180-190.

Yu, W., YAng, Y.C., SAvitsky, A., Alford, D., Brown, C., Wescoat, J., Debowicz, D. and Robinson, S. 2013. The Indus Basin of Pakistan. The Impacts of Climate Risks on Water and Agriculture. Washington D.C., The World Bank. http://index.gain.org/ranking/vulnerability http://reliefweb.int/map/world/world-climatechange-vulnerability-index-2015

http://www.gain.org/

http://www.natureserve.org/conservation-tools/ climate-change-vulnerability-index https://germanwatch.org/en/cri https://maplecroft.com/about/news/ccvi.html 